\title{
Research on Network Resources Construction of College Elaborate Courses
}

\author{
Ying Luo ${ }^{1,}$, Xinxin Wang ${ }^{2, b}$ \\ ${ }^{1}$ TVET Research Institute, Jiangxi Science \& Technology Normal University, Nanchang, China \\ ${ }^{2}$ Education School, Jiangxi Science \& Technology Normal University, Nanchang, China \\ amooonly@126.com; '1270731275@QQ.com
}

Keywords: colleges and universities; elaborate courses; network resources

\begin{abstract}
The construction of elaborate courses is an important job in colleges and universities, spending a lot of money and effort. In order to make elaborate courses better realize resource sharing, the paper analyzes the problems existing in network resource construction of elaborate courses, and puts forwards the corresponding opinions and suggestions.
\end{abstract}

\section{Introduction}

High quality teaching resources is not only the foundation of university personnel training, but also the important manifestation of the school running characteristics. Elaborate courses is an important part of college teaching resources, and is an important job of university curriculum construction and reform, which has great significance and good demonstration effect to improve teaching quality and deepen teaching reform, and plays a leading role.

Arrange, induct and shorten the content of elaborate course through modern teaching means to build the network curriculum. Then managing elaborate courses through modern information technology, network communication technology is the embodiment of advanceness and scientificity of elaborate courses. At the same time, the goal of elaborate courses is to achieve resources sharing, so the website should meet the basic requirement and realize open communication and wide sharing.

In the construction of college elaborate courses, how to improve the utilization rate of network teaching resources, how to fully meet the needs of teachers and students, how to better realize quality resources sharing, and how to use the information technology to manage and update the site are the issues universities should think deeply in the process of elaborate course construction.

\section{Problems existing in the network resource construction of college elaborate course}

Lack effective promotion mechanism of elaborate course. The construction of elaborate course in colleges and universities are mostly driven by policy as an external resource. Therefore, all colleges and universities attach great importance to declare the work of elaborate course and spend a lot of energy in choosing excellent course. In the construction of network resources, some elaborate courses' network resource is hastily built; the goal is not clear, the thought is not clear and lack overall planning. Generally speaking, the starting point is to pass the "approval" and win the title "elaborate course", rather than to carry out teaching. Therefore, most of them pay attention to pre declaration, ignore later management and resource utilization, and lack internal motive force of using network resource of elaborate courses.

Network resource construction lacks long-term planning. Without technical support and technical guidance, the network resource development and construction of elaborate course has no suitable and unified network teaching platform. At present, our country carry out the construction of elaborate course in the form of project and build it for the declaration. The fund is invested one time and the construction period is short. Since the inspection and supervision mechanism after the completion is not perfect, many courses lack long-term maintenance, use target and continued construction platform. The follow-up construction quality of elaborate course is uneven, and some are not fine. 
What's more, course website puts the relevant contents on a page in accordance with the declaration conditions and requirements, which is difficult to be said as high-quality teaching resources.

Network resource construction lacks awareness of intellectual property protection. The application and assessment of quality course needs to be realized through the network, the course website is a carrier to realize network resource sharing, but the intellectual property protection of network resource has not be solved properly and the resources are in the state of "no protection". Many excellent course resources are shared in the network, resulting in that the labor of teachers can not be well protected. But "over protection", refusing network sharing, will not only cause resource waste, but also go against the requirement of the ministry of education. How to let "no protection" and "over protection" reach agreement is the problem we need to consider. If the intellectual property rights can not be protected, it will not only hurt teachers' legitimate rights and interest, but also hit teachers' enthusiasm to participate in the development and sharing of teaching resources.

The interaction of resource sharing is bad. Network resource of elaborate courses provide a number of high-quality teaching resource which can be acquired freely, so many current domestic colleges and universities launch the excellent course website link on the school website to let others obtain teaching resource through access. However, many websites haven't provided the users with platform of mutual learning, exchange and discussion, even if, it is just useless. Because no one replies question online, online QQ is only a form, and there is no background response. In fact, the quality course website is to create virtual learning environment for students. If lack communication and interaction between teachers and students, it will make that teachers can not understand the users' situation, comments and feedback information, and can not promptly adjust and continue to increase and update the related function of users' demand, which can not reflect new course teaching design, new research progress and new function service, can not make the network resource of elaborate courses to achieve keeping pace with the times, and will affect the learning effect for users at the same time.

\section{The key work of network resource of college elaborate course}

The network resource construction of elaborate course should carry out the overall planning and dynamic management. In the process, universities should play a leading and guiding role, clarify the basic idea and goal, and implement overall planning, dynamic management and overall monitoring. In addition, colleges also should do well in agreement management, improve the supervision mechanism, strengthen intercollegiate exchanges, carry out interim evaluation and examination, strictly organize acceptance evaluation work, and establish scientific and efficient evaluation mechanism. Universities need to supervise and guide independent schools to do the following work: at earlier stage, analyze the demand of network resource; at mid-term, plan the network course system and integrate network teaching content; after the network resource sharp, test, tryout and further improve the later site management and updating work.

Increase the promotion and application of network resource and elaborate course. Since the ministry of education starts the construction of national quality curriculum, the number of national, provincial and school elaborate courses construction has quite a large scale, covering a very extensive field and rich curriculum resources. Therefore, in order to obtain effective sharing, it is urgent to increase the propaganda and expand the awareness rate of elaborate course. For example, in some influential education websites, open promotion column of elaborate course or publish public service advertising to expand the awareness rate of elaborate course website. In addition, the students know the elaborate course through teachers, so it requires teachers to strengthen the propaganda among students and use task driven approach to let students use the elaborate course. What' more, the school should increase the propaganda way. In the home page of campus net, academic office affairs website and various departments, provide the links of elaborate course; in the campus forum, promote quality curriculum; increase the school newspaper, school broadcasting and other offline media publicity.

Build unified platform of resource sharing. Only guarantee the course website can be accessed, the network resource of elaborate course can be used or shared. In order to realize the resource sharing, it 
must have a suitable sharing platform as the basis. Establish unified platform for elaborate course to store them, so as to facilitate access and maintenance. The unified platform should have access to statistics, feedback and other functions, to promote the evaluation of high quality course and improve the quality of elaborate course. The school should set up a special group and provide the support on video recording and site production from the technology, personnel and other aspects. In addition to technical support, give certain training to elaborate course content construction, so as to make it become high-quality and consistent with the characteristics of network learning, fully use technical ability of network curriculum. In order to realize the effective sharing of curriculum resources, the standard can not be less. We should formulate unified curriculum design process, module settings, and curriculum resources publishing format, to achieve the compatibility of different browsers. In addition, unified platform should provide curriculum forum and support mutual discussion between visitors. Elaborate course charger also can get information feedback from the discussion of visitors, so as to improve curriculum construction and further improve the quality of curriculum resources.

Establish and perfect the incentive mechanism evaluation. At present, the utilization rate of quality course is low, it emphasis the construction and lights utilization, which has become a universal phenomenon. The main reason is lacking a perfect evaluation and incentive mechanism. Most of teachers just complete the task required when declaring elaborate course, but don't pay attention to the following application and updating. Therefore, post evaluation will play the role of supervision and promotion. On one hand, it can inspire teachers to continue to improve and perfect their own quality course in accordance with the regulations; on the other hand, it can promote timely communication and exchange between teachers and administrators to find and solve the unexpected problems and difficulties. The school should check the online teaching resources periodically or nonperiodically, especially the curriculum contents and teaching application degree. For example, through the click rate of course site, collect and analyze users' feedback, timely understand the radiation effect of course teaching content and defects of course cyber source, and adopt countermeasures according to the existing problems. In general, the school often provides matching funds for the excellent course of the national and provincial title to play good role of supporting fund. In the construction and maintenance of the cyber source, it needs a lot of time and energy. Full amount of matching funds can be paid to those having better effect on construction, maintenance and use. At the same time, in the calculation of teaching workload, the people who are responsible for quality course should be added appropriated; to those with poor effect, reduce or not give matching funds.

\section{Conclusion}

Elaborate course construction is a systematic project, and network resource construction of elaborate course is a continuous process, which not only has positive significance for improving the teaching quality and teaching reform in colleges and universities, but also provides good platform for the development of network information education.

Elaborate course should often update. In order to make the network resource construction of elaborate course produce lasting power, it is necessary to combine the technical support, the process construction and quality security to achieve high quality education resources sharing and application goals.

\section{References}

[1]Yulin Zhou. Research on creativity training in the process of electronic courses[J]. Science and technology education, 2010(30).

[2]Wen Hai. Problems and countermeasures of network resources construction of elaborte course[J]. Education and occupation, 2009(15):155-156. 
[3]Cong Xiang. Optimizing strategies of elaborate course resource construction[J].Chinese education information, 2008(15):8-10.

[4]Chuanchuan Liu, Yuwen Ning, Ling Gao, etc. Research on strategies of the national excellent course website operation and resource updating[J]. Modern education technology, 2009(12):61-63.

[5]Xiaoqiu Shi, Wei Xue. Problems and countermeasures in the construction of resource sharing of excellent course[J]. Chinese higher education research, 2005(1):44-46. 